Research Article

\title{
Study of influence of nicorandil on hypoglycemic action of glibenclamide in alloxan induced diabetic rats
}

Department of Pharmacology, JSS Medical College, Shivrathreshwara Nagar, Mysore - 570015, Karnataka State, India

Received: 18 July 2016 Accepted: 31 August 2016

*Correspondence to: Dr. Syed Mohsin Ahmed, Email: syedmohsin1974.sa@ gmail.com

Copyright: (C) the author(s), publisher and licensee Medip Academy. This is an openaccess article distributed under the terms of the Creative Commons Attribution NonCommercial License, which permits unrestricted noncommercial use, distribution, and reproduction in any medium, provided the original work is properly cited.

\author{
Syed Mohsin Ahmed*
}

\begin{abstract}
Background: To assess the interaction between ATP - sensitive potassium channel opener nicorandil and potassium channel blocker glibenclamide in alloxan - induced diabetic rats and to evaluate whether nicorandil antagonizes the oral hypoglycaemic action of glibenclamide.

Methods: Insulin secretion involves ATP sensitive $\mathrm{K}+$ channel blockade, the influence of ATP sensitive $\mathrm{K}+$ channel opener was studied in combination with its blocker. Albino rats of wistar strain, weighing between 200 - 250 grams of either sex were used for the study. Diabetes was induced by injecting alloxan monohydrate $2 \%$ solution intra - peritoneally in a dose of $150 \mathrm{mg} / \mathrm{kg}$ body weight. Animals with fasting blood glucose between $200-300 \mathrm{mg} / \mathrm{dl}$ were selected and were divided into 3 groups of six animals each. Group I received $2 \%$ gum acacia, group II was given glibenclamide $(0.5 \mathrm{mg} / \mathrm{kg}$ body weight $)$ and group III was treated with nicorandil $(0.3 \mathrm{mg} / \mathrm{kg}$ body weight $)+$ glibenclamide $(0.5 \mathrm{mg} / \mathrm{kg}$ body weight) respectively orally for 30 days. Fasting blood sugar was recorded in all rats on $1^{\text {st }}, 3^{\text {rd }}, 7^{\text {th }}, 14^{\text {th }}, 21^{\text {st }}$ and $28^{\text {th }}$ days.

Results: Results show that glibenclamide has significantly reduced the blood sugar levels $(\mathrm{P}<0.05)$, whereas when glibenclamide was combined with nicorandil there was a significant rise in blood sugar level $(\mathrm{P}<0.05)$.

Conclusions: The study shows that hypoglycaemic action of glibenclamide is antagonized by nicorandil as indicated by worsening of diabetes, probably by blocking the $\mathrm{K}+$ channel closing action of glibenclamide. These findings suggest that $\mathrm{K}+$ channel openers should be avoided with $\mathrm{K}+$ channel blockers in presence of diabetes.
\end{abstract}

Keywords: Diabetes mellitus, Albino rats, Alloxan monohydrate, Fasting blood sugar, Glibenclamide, Nicorandil

\section{INTRODUCTION}

Diabetes and hypertension are the commonest clinical problems of the present day in past middle age group individuals and they may coexist. Further diabetes mellitus may increase the risk of macro vascular complications like hypertension, angina, myocardial infarction, cardiomyopathy, stroke and peripheral vascular disease, as well as microvascular diseases like retinopathy, nephropathy and neuropathy. The management of individual disease is much easier than when they exist together. As diabetes is most often associated with hypertension/angina in some patients, there is a need to prescribe vasodilators. Among vasodilators nicorandil is one drug which is used in angina and hypertension.

\section{METHODS}

Wide varieties of drugs are used in the management of hypertension and angina. Potassium channel openers (like nicorandil) are one of the groups of drugs that are useful in angina, which by opening the ATP sensitive potassium channels brings about hyper polarization and produces vasodilatation of vascular smooth muscles. This vasodilator effect of nicorandil is partly antagonized by glibenclamide. ${ }^{1}$ Drugs that have their primary site of action at arteriolar level (calcium channel blockers and potassium channel openers) are not beneficial in the treatment of angina. However nicorandil also exerts a nitrate like effect, stimulating guanylyl cyclase to increase cyclic GMP, primarily in epicardial coronary arteries including stenotic segments producing 
vasodilatation. $^{2}$ Hence this drug is used in the management of angina/ischemic heart disease. Further minoxidil and diazoxide, which are potassium channel openers have been used since long in severe hypertension and hypertensive emergencies. They also act by opening ATP sensitive potassium channel bringing about hyper polarization and vasodilatation. One of the commonest side effects of diazoxide is hyperglycemia. This is due to opening of potassium channel in beta cells producing hyper polarization that inhibits insulin release. Thus hyperglycemia is the main problem with use of diazoxide in type 2 diabetic patients who are on oral hypoglycemic drugs. ${ }^{3}$ Like diazoxide the novel potassium channel opener (nicorandil) also activates ATP sensitive potassium channels, which are present both on vascular smooth muscles and membrane of beta cells of pancreas. Hence nicorandil in addition to producing vasodilatation in coronaries may also inhibit insulin secretion.

Hence in a situation where type 2 diabetes is associated with ischemic heart disease/hypertension, there may be a chance that nicorandil may be co-prescribed with glibenclamide for management of angina and this may worsen diabetic control. Thus in anticipation of the above action of nicorandil, this study has been taken up in albino rats. Diabetes was induced with intra - peritoneal injection of $2 \%$ alloxan. The results were analysed by noting the effect of nicorandil on insulin secretory action of glibenclamide when it is administered orally.

\section{Mechanism of action of glibenclamide}

ATP sensitive potassium channels (K-ATP) determine the resting membrane potential in $\beta$-cells. Glucose stimulation of insulin secretion begins with its transport into the $\beta$-cells via a membrane transporter called GLUT2. Glucose phosphorylation by glucokinase is the ratelimiting step that controls glucose regulated insulin secretion. Further metabolism of glucose - 6 phosphate via glycolysis generates ATP which inhibits the activity of an ATP- sensitive potassium channel. This channel consists of two separate proteins: one is the receptor for certain oral hypoglycemics (example: sulfonylurea, meglitinides), the other is an inwardly rectifying $\mathrm{K}+$ channel protein. Inhibition of this $\mathrm{k}+$ channel induces $\beta$ cell membrane depolarization, which opens voltagedependent calcium channels, leading to calcium influx. This calcium signal induces insulin secretion. Second generation sulfonylurea's (like glibenclamide) are the commonly used oral hypoglycemic drugs in the management of type 2 diabetes mellitus which by closing the ATP sensitive potassium channels brings about partial depolarization and produce release of insulin from beta cells.

\section{Mechanism of action of alloxan}

The unique capability of alloxan to selectively destroy the pancreatic $\beta$-cell was first described by Dunn et al. ${ }^{4}$ The toxic effect of alloxan in these cells seems to be closely related to increased cellular permeability and morphological abnormalities of plasma membrane of rodents exposed to alloxan has been described. ${ }^{5}$ Alloxan administration leads to a decrease in islet superoxide dismutase activity. Recent studies have suggested mitochondrial dysfunction in the pancreatic $\beta$-cells may also be involved in the diabetogenic action of alloxan. As a result, free calcium levels may be increased. Excess calcium concentration in the cell cytoplasm has been known to be noxious and leads to cell death. ${ }^{6,7}$ Alloxan has shown to cause IDDM in dogs, cats, sheep, rabbits, mice, monkeys, fish, turtles and birds. ${ }^{8}$ Only guinea pig is insensitive to the diabetogenic action of alloxan.

Administration of alloxan in to the peritoneal cavity of 2 day old rat has been reported to cause an experimental situation similar to that seen in NIDDM. ${ }^{6}$ Alloxan diabetic animals also possess diabetic complications such as cardiomyopathy, gastroenteropathy and autonomic neuropathy.'

\section{Methods of study}

\section{Animals}

Animals used are albino rats of wistar strain weighing between 200-250 grams of either sex. The animals were randomly selected from central animal facility, JSS Medical College, Mysore. Animals were d into divided into 3 groups, each group with 6 animals. Animals were fed with laboratory food and water. The institutional animal ethical committee approved the protocol of this study.

\section{Drugs and chemicals}

- $2 \%$ Alloxan monohydrate: for induction of diabetes, stored between 2 - 8 degree centigrade ${ }^{10}$

- $\quad 2 \%$ Gum acacia as suspending agent, a dried gummy exudate obtained from bark of acacia arabica ${ }^{11}$

- Glibenclamide (0.5 mg per $\mathrm{kg}$ body weight): $2^{\text {nd }}$ generation sulfonylurea, standard drug

- $\quad$ Nicorandil (0.3 mg per $\mathrm{kg}$ body weight): $\mathrm{k}+$ channel opener, test drug. ${ }^{12}$

\section{Equipment's}

Mouth gag, polythene tube, tuberculin syringe, glucometer

\section{Methodology}

Animals were divided into three groups with six rats in each group and were fed with pellet diet and water and acclimatized to laboratory conditions before carrying out any experimental work. For measuring fasting blood glucose, blood was collected from the rat's tail vein by tail cutting method. Following overnight fasting diabetes was induced by injecting freshly prepared $2 \%$ alloxan monohydrate solution dissolved in $0.9 \%$ sodium chloride 
intra-peritoneally in a dose of $150 \mathrm{mg}$ per $\mathrm{kg}$ body weight. ${ }^{13}$ Following injection, animals were carefully observed for the first 24 hours for any evidence of allergic reaction, behavioural changes and convulsions. No untoward reaction was observed in any animal. Fasting blood glucose was recorded daily morning at around $9.00 \mathrm{am}$ for one week. Animals developed stable hyperglycemia after 4-5 days. Only those animals with blood glucose between 200-300 mg/ dl were selected for the study. Later they were divided into 3 groups, each group having 6 animals. The groups were named as control, standard and test group respectively.

\section{Administration of drugs}

Animals belonging to different groups were fed with the following agents.

\section{Control group}

6 alloxan induced diabetic rats, orally fed with $0.5 \mathrm{ml}$ of $2 \%$ gum acacia for 30 days.

\section{Standard group}

6 alloxan induced diabetic rats, orally fed with $0.5 \mathrm{ml}$ of $2 \%$ gum acacia + glibenclamide $0.5 \mathrm{mg} / \mathrm{kg}$ body weight for 30 days.

\section{Test group}

6 alloxan induced diabetic rats, orally fed with $0.5 \mathrm{ml}$ of $2 \%$ gum acacia + nicorandil $0.3 \mathrm{mg} / \mathrm{kg}$ body weight + glibenclamide $0.5 \mathrm{mg} / \mathrm{kg}$ body weight for 30 days.

Fasting blood glucose was recorded in all the animals of each group on $0,1^{\text {st }}, 3^{\text {rd }}, 7^{\text {th }}, 14^{\text {th }}, 21^{\text {st }}$ and $28^{\text {th }}$ day. Insulin secreting action of the drug is assessed by its capacity to decrease FBS levels and the antagonism of insulin secretory action of the drug by increase in FBS levels.

The results will be analysed by calculating the mean values, the standard deviation, the standard error, the ' $t$ 'test, 'p'- value and the analysis of variance (ANOVA). PValue is the standard table value of ' $t$ ' at $(12-2)=10$ degree of freedom for $0.05(5 \%)$ level of significance, $\mathrm{P}<$ $0.05=$ significant

$\mathrm{P}>0.05=$ Not significant

The formulas are enclosed in annexure.

\section{RESULTS}

\section{Blood glucose comparison within each group}

There was no significant difference in the mean values of blood glucose level from day ' 0 ' - day ' 28 ' in the diabetic control group $(\mathrm{p}>0.05)$.

In the standard (glibenclamide) group the difference in the mean values of blood glucose level was found to be statistically significant between 0 to1st day, 1 st to 3 rd day, $3^{\text {rd }}$ to $7^{\text {th }}$ day, $7^{\text {th }}$ to $14^{\text {th }}$ day and $21^{\text {st }}$ to $28^{\text {th }}$ day (p $<$ $0.05)$.

In the test (glibenclamide + nicorandil) group the difference in mean values of blood glucose level was not found to be statistically significant $(\mathrm{P}>0.05)$ between 0 to $1^{\text {st }}$ day and $1^{\text {st }}$ to $3^{\text {rd }}$ day but later the difference was found statistically significant $(\mathrm{P}<0.05)$ between $3^{\text {rd }}$ to $7^{\text {th }}$ day, $7^{\text {th }}$ to $14^{\text {th }}$ day, $14^{\text {th }}$ to $21^{\text {st }}$ day and $21^{\text {st }}$ to $28^{\text {th }}$ day.

Table 1: The FBS values in $\mathrm{mg} / \mathrm{dl}$ of $1^{\text {st }}$ animal of each group from 0 to $28^{\text {th }}$ day.

\begin{tabular}{|llllllllll|}
\hline Si. no. & Groups & $\mathbf{0}$ day & $\mathbf{1}^{\text {st }}$ day & $\mathbf{3}^{\text {rd }}$ day & $\mathbf{7}^{\text {th }}$ day & $\mathbf{1 4}^{\text {th }}$ day & $\mathbf{2 1}^{\text {st }}$ day $^{\mathbf{2 8}^{\text {th }}}$ day \\
\hline A-1 & Diabetic control & 281 & 278 & 280 & 277 & 282 & 279 & 280 \\
\hline B-1 & Standard (G) & 229 & 168 & 145 & 128 & 110 & 112 & 108 \\
\hline C-1 & Test group $(G+N)$ & 248 & 223 & 243 & 309 & 323 & 328 & 334 \\
\hline
\end{tabular}

Table 2: The FBS values in $\mathrm{mg} / \mathrm{dl}$ of $2^{\text {nd }}$ animal of each group from 0 to $28^{\text {th }}$ day.

\begin{tabular}{|llllllllll|} 
Si. no. & Groups & $\mathbf{0}$ day & $\mathbf{1}^{\text {st }}$ day & $\mathbf{3}^{\text {rd }}$ day & $\mathbf{7}^{\text {th }}$ day & $\mathbf{1 4}^{\text {th }}$ day & $\mathbf{2 1}^{\text {st }}$ day & $\mathbf{2 8}^{\text {th }}$ day \\
\hline A-2 & Diabetic control & 288 & 291 & 281 & 286 & 283 & 280 & 281 \\
\hline B-2 & Standard $(G)$ & 267 & 204 & 167 & 162 & 156 & 130 & 118 \\
\hline C-2 & Test group $(\mathrm{G}+\mathrm{N})$ & 273 & 246 & 276 & 266 & 281 & 302 & 320 \\
\hline
\end{tabular}

Table 3: The FBS values in $\mathrm{mg} / \mathrm{dl}$ of $3^{\text {rd }}$ animal of each group from 0 to $28^{\text {th }}$ day.

\begin{tabular}{|lllllllll|}
\hline Si. no. & Groups & 0 day & $\mathbf{1}^{\text {st }}$ day & $\mathbf{3}^{\text {rd }}$ day & $\mathbf{7}^{\text {th }}$ day & $\mathbf{1 4}^{\text {th }}$ day & $\mathbf{2 1}^{\text {st }}$ day & $\mathbf{2 8}^{\text {th }}$ day \\
\hline A-3 & Diabetic control & 240 & 238 & 240 & 242 & 239 & 237 & 235 \\
\hline B-3 & Standard $(G)$ & 250 & 220 & 210 & 198 & 142 & 167 & 148 \\
\hline C-3 & Test group $(G+N)$ & 268 & 301 & 286 & 305 & 308 & 312 & 336 \\
\hline
\end{tabular}


Table 4: The FBS values in $\mathrm{mg} / \mathrm{dl}$ of $4^{\text {th }}$ animal of each group from 0 to $28^{\text {th }}$ day.

\begin{tabular}{|lllllllll|}
\hline Si. no. & Groups & $\mathbf{0}$ day & $\mathbf{1}^{\text {st }}$ day & $\mathbf{3}^{\text {rd }}$ day & $\mathbf{7}^{\text {th }}$ day & $\mathbf{1 4}^{\text {th }}$ day & $\mathbf{2 1}^{\text {st }}$ day $^{\mathbf{2 8}^{\text {th }}}$ day \\
\hline A-4 & Diabetic control & 230 & 232 & 228 & 228 & 224 & 226 & 229 \\
\hline B-4 & Standard $(G)$ & 242 & 218 & 206 & 182 & 161 & 138 & 122 \\
\hline C-4 & Test group $(G+N)$ & 248 & 246 & 248 & 309 & 316 & 321 & 332 \\
\hline
\end{tabular}

Table 5: The FBS values in $\mathrm{mg} / \mathrm{dl}$ of $5^{\text {th }}$ animal of each group from 0 to $28^{\text {th }}$ day.

\begin{tabular}{|lllllllll|}
\hline Si. no. & Groups & $\mathbf{0}$ day & $\mathbf{1}^{\text {st }}$ day & $\mathbf{3}^{\text {rd }}$ day & $\mathbf{7}^{\text {th }}$ day & $\mathbf{1 4}^{\text {th }}$ day & $\mathbf{2 1}^{\text {st }}$ day $^{\mathbf{2 8}^{\text {th }}}$ day \\
\hline A-5 & Diabetic control & 282 & 278 & 283 & 280 & 276 & 281 & 279 \\
\hline B-5 & Standard $(G)$ & 276 & 242 & 236 & 212 & 186 & 152 & 146 \\
\hline C-5 & Test group $(G+$ N) & 277 & 276 & 278 & 300 & 307 & 312 & 329 \\
\hline
\end{tabular}

Table 6: The FBS values in $\mathrm{mg} / \mathrm{dl}$ of $6^{\text {th }}$ animal of each group from 0 to $28^{\text {th }}$ day.

\begin{tabular}{|lllllllll|}
\hline Si. no. & Groups & $\mathbf{0}$ day & $\mathbf{1}^{\text {st }}$ day & $\mathbf{3}^{\text {rd }}$ day & $\mathbf{7}^{\text {th }}$ day & $\mathbf{1 4}^{\text {th }}$ day & $\mathbf{2 1}^{\text {st }}$ day $^{\mathbf{2 8}^{\text {th }}}$ day \\
\hline A-6 & Diabetic control & 280 & 281 & 278 & 279 & 275 & 276 & 274 \\
\hline B-6 & Standard $(G)$ & 282 & 260 & 242 & 202 & 176 & 138 & 120 \\
\hline C-6 & Test group $(G+N)$ & 272 & 245 & 238 & 302 & 312 & 333 & 342 \\
\hline
\end{tabular}

Table 7: The mean values of blood glucose levels and Std. deviations in different groups of animals.

\begin{tabular}{|c|c|c|c|c|c|c|c|}
\hline Groups & 0 day & $1^{\text {st }}$ day & $3^{\text {rd day }}$ & $7^{\text {th }}$ day & $14^{\text {th }}$ day & $21^{\text {st }}$ day & $28^{\text {th }}$ day \\
\hline Diabetic control & $267 \pm 22.8$ & $266 \pm 24.0$ & $265 \pm 24.3$ & $265 \pm 24.0$ & $263 \pm 25.1$ & $263 \pm 24.8$ & $263 \pm 24.2$ \\
\hline Standard & $258 \pm 18.9$ & $218 \pm 31.7$ & $201 \pm 38.0$ & $180 \pm 31.1$ & $161 \pm 27.0$ & $139 \pm 18.7$ & $127 \pm 16.2$ \\
\hline Test-group & $264 \pm 12.9$ & $256 \pm 25.5$ & $261 \pm 20.0$ & $298 \pm 16.0$ & $307 \pm 14.0$ & $318 \pm 11.5$ & $332 \pm 7.3$ \\
\hline
\end{tabular}

Table 8: A comparison of percentage of reduction in blood glucose levels in case of standard and percentage of increase in blood glucose levels in case of combination of glibenclamide with nicorandil.

\begin{tabular}{|llllllll|}
\hline Group & $\mathbf{1}^{\text {st }}$ day & $\mathbf{3}^{\text {rd }}$ day & $\mathbf{7}^{\text {th }}$ day & $\mathbf{1 4}^{\text {th }}$ day & $\mathbf{2 1}^{\text {st }}$ day & $\mathbf{2 8}^{\text {th }}$ day & Mean \\
\hline Standard $\downarrow$ & $15.17 \%$ & $21.78 \%$ & $29.96 \%$ & $37.35 \%$ & $45.91 \%$ & $50.58 \%$ & $33.45 \%$ \\
\hline Test drug $\uparrow$ & $5.3 \%$ & $1.1 \%$ & $12.8 \%$ & $16.2 \%$ & $20.4 \%$ & $25.7 \%$ & $18.77-3.20=15.57 \%$ \\
$(\mathrm{G}+\mathrm{N})$ & reduction & reduction & increase & increase & increase & increase & \\
\hline
\end{tabular}

Table 9: The mean values and standard deviation of blood glucose levels in standard (G) and test (G+N) groups and their significance.

\begin{tabular}{|lllll|}
\hline Day & Standard $(\mathbf{G})$ & Test group $(\mathbf{G}+\mathbf{N})$ & P- value & Inference \\
\hline 0 & $258 \pm 18.9$ & $264 \pm 12.9$ & $>0.05$ & NS \\
\hline 1 & $218 \pm 31.7$ & $256 \pm 25.5$ & $<0.05$ & $\mathrm{~S}$ \\
\hline 3 & $201 \pm 38$ & $261 \pm 20$ & $<0.05$ & $\mathrm{~S}$ \\
\hline 7 & $180 \pm 31.1$ & $298 \pm 16$ & $<0.05$ & H S \\
\hline 14 & $161 \pm 27$ & $307 \pm 14$ & $<0.05$ & H S \\
\hline 21 & $139 \pm 18.7$ & $318 \pm 11.5$ & $<0.05$ & H S \\
\hline 28 & $128 \pm 16.2$ & $332 \pm 7.3$ & $<0.05$ & H S \\
\hline
\end{tabular}

$\mathrm{P}<0.05$ = Significant $(\mathrm{S})$ or highly significant $(\mathrm{HS}) ; \mathrm{G}=$ Glibenclamide $; \mathrm{N}=$ Nicorandil.

\section{Blood glucose comparison between the groups}

Between the standard (glibenclamide) and test (glibenclamide + nicorandil) group.
The difference between the mean values of blood glucose levels of standard and test group was found to be statistically significant on $1^{\text {st }}$ and $3^{\text {rd }}$ day and highly significant from $7^{\text {th }}$ day to the $28^{\text {th }}$ day. i.e., the test drug combination has caused significant rise in blood glucose level when compared to standard. 


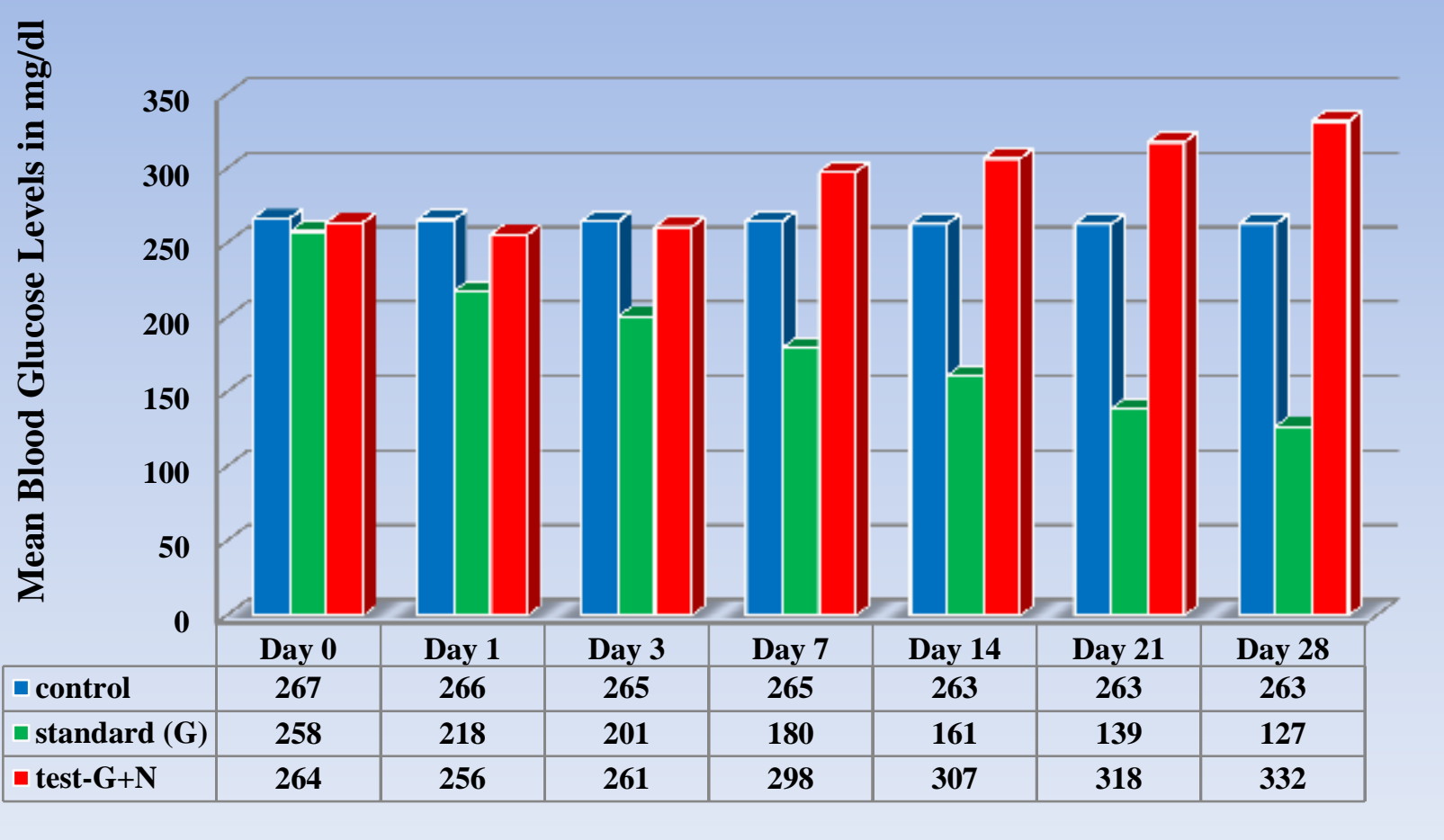

Figure 1: Multiple bar chart of comparison of mean blood glucose levels from day 0 to day 28.

\section{DISCUSSION}

Diabetes is most commonly associated with hypertension and ischemic heart disease, for which a combination of drug therapy is required. The introduction of insulin secretogogues like sulfonylureas and meglitinides has revolutionized the treatment of diabetes along with biguanides and thiazolidinediones, which reduce insulin resistance/produce insulin sparing effect.

In addition to nitrates, potassium channel openers are the other group of drugs that are useful in hypertension and ischemic coronary heart disease. It has been found that hyperglycemia is one of the commonest side effects of potassium channel opener like diazoxide due to inhibition of insulin release. ${ }^{3}$

In the light of this, the novel potassium channel opener nicorandil has been investigated to see whether it antagonizes the hypoglycemic effect of potassium channel blocker glibenclamide. The results obtained were compared with the hypoglycemic effect of the standard drug glibenclamide.

Albino rats of Wistar strain, weighing between 200-250 gms of either sex were used for the study. Chemical diabetes model was used as an experimental method for the study. In this method, alloxan monohydrate $2 \%$ solution was injected intraperitoneally in a dose of 150 $\mathrm{mg} / \mathrm{kg}$.b.wt as described by Dunn et al. ${ }^{4}$ In this study the standard drug glibenclamide was given in the dose of 0.5 $\mathrm{mg} / \mathrm{kg}$.b.wt and the test drug combination of nicorandil in the dose of $0.3 \mathrm{mg} / \mathrm{kg}$.b.wt $12+$ glibenclamide 0.5 $\mathrm{mg} / \mathrm{kg}$.b.wt was given orally for 30 days in different groups of diabetic animals.

The group in which glibenclamide was given showed a fall in blood glucose level. The mean fall in blood glucose level was $33.45 \%$ over 28 days which was found to be statistically significant.

The group in which both glibenclamide and nicorandil were given showed an initial fall in blood glucose level by $5.3 \%$ and $1.1 \%$ on $1^{\text {st }}$ and $3^{\text {rd }}$ day, which was found to be statistically not significant. Later the same group showed a mean rise in blood glucose level of $18.77 \%$ from $7^{\text {th }}$ to $28^{\text {th }}$ day, which was found to be statistically significant.

Statistical analysis was done using paired students ' $t$ ' test, $\mathrm{t}$-values obtained in each group were compared with $\mathrm{P}$ value (standard table value of ' $t$ ') at 10 degree of freedom for $0.05(5 \%)$ level of significance, $\mathrm{P}<0.05$ (significant) and $\mathrm{P}>0.05$ (not significant).

The minimum number of animals required to conduct the study is 6 in each group and hence 6 animals were included in each group. The above results indicate that nicorandil opposes the hypoglycemic effect of glibenclamide in diabetic rats. 
Because of pharmacokinetic and pharmacodynamic variations between animal and human species further studies are required to substantiate these results in human diabetic subjects where the minimum number of subjects required in each group is 30 .

\section{CONCLUSION}

Thus from the above study it is concluded that nicorandil when added to glibenclamide in alloxan induced diabetic rats has shown the following effects;

- It has worsened diabetes by antagonizing the hypoglycemic effect of glibenclamide probably by blocking the potassium channel closing action of glibenclamide on ATP sensitive $\mathrm{K}+$ channels on the surface of beta cells of pancreas.

- These findings suggest that potassium channel openers should be avoided when potassium channel blockers are being used as oral hypoglycemics in the management of diabetes. However if coronary vasodilator effect is required for angina in presence of diabetes, then other vasodilators like nitrates can be preferred.

\section{ACKNOWLEDGEMENTS}

It is with deep sense of gratitude and respect authors express my most cordial and humble thanks to the Professor and Head, department of pharmacology, JSS Medical College, Mysore Dr. BM Prakash for allowing me to conduct this study.

Authors wish to thank with deep sense of gratitude to principal Dr. SB Vasanth Kumar for permitting me to do this study and to use facilities for the purpose. Authors also acknowledge Sai Mirra pharmaceuticals private limited for having supplied nicorandil in a pure form for this study and authors also thankful to sigma for supplying pure form of alloxan.

Finally authors wish to thank the animal house technician of JSS medical college, Mysore for his assistance and cooperation while conducting the study.

Funding: No funding sources Conflict of interest: None declared

Ethical approval: Not required

\section{REFERENCES}

1. Kerins DM, Robertson RM, Robertson D. Drugs used for the treatment of myocardial ischemia. In: Hardman JG, Limbird LE, eds. Goodman and Gilman's The Pharmacological Basis of Therapeutics. $10^{\text {th }}$ ed. New York, NY: McGraw-Hill; 2001:1679-80.

2. Lablanche JM, Bauters C, McFadden FP, Quandalle $\mathrm{P}$, Bertrand ME. Potassium channel activators in vasospastic angina. Eur Heart J. 1993;14(supplement B):22-4.

3. Oates JA, Brown NJ. Antihypertensive agents and drug therapy of hypertension. In: Hardman JG, Limbird LE, eds. Goodman and Gilman's The Pharmacological Basis of Therapeutics. $10^{\text {th }}$ ed. New York, NY: McGraw-Hill; 2001:890-891.

4. Dunn JS, Sheehan HL, Mcletchie NGB. Necrosis of islets of langerhans produced experimentally. The Lancet. 1943;1(6242):484-7.

5. Watkins D, Cooperstein SJ, Lazarow A. Effect of alloxan on permeability of pancreatic islet tissue in vitro. Am J Physiol. 1964;207:436-40.

6. Bailey CC. Alloxan diabetes. Vit Horm. 1949;7;36582.

7. Kelestimur F, Kokker H. Alloxan induced diabetes mellitus in albino rats. Ind J Pharmacol. 1994;47:725.

8. Bell RH, Hye RJ. Animal models of diabetes mellitus: physiology and pathology. J Surg Res. 1983;35(5):433-60.

9. Lekenn FDW. Alloxan diabetes. Pharmacological reviews. 1948;28:304.

10. Secich P, Wicks F, Lori T. In: Sigma Chemical company, eds. Biochemical organic compounds for research and diagnostic clinical reagents. USA;1995:78.

11. Windholz M, Merck and Co. The Merck index. $10^{\text {th }}$ ed. Rahway, NJ; 1983:260.

12. Kennedy MSN, Masharani U. Pancreatic hormones and antidiabetic drugs. In: Katzung BG, Trevor AJ, eds. Basic and Clinical Pharmacology. $9^{\text {th }}$ ed. New York, NY: McGraw-Hill; 2004:705.

13. Altan. Experimental model of diabetes. Pharmacological reviews. 1989;40:72-5.

Cite this article as: Ahmed SM. Study of influence of nicorandil on hypoglycemic action of glibenclamide in alloxan induced diabetic rats. Int $\mathbf{J}$ Basic Clin Pharmacol 2016;5:2146-52. 


\section{Annexure}

\section{Statistical formulae}

If $x 1, x 2-\ldots$ - $x$ are ' $n$ ' Observations [say $x=$ blood glucose level in mg/dl] then,

1) The Arithmetic mean ( AM ) or $\mathrm{x}$ is denoted by the formula

$\mathrm{X}=\mathrm{A} \cdot \mathrm{M}=\left[\mathrm{X} 1+\underline{\mathrm{X} 2+\ldots+\mathrm{Xn}]=\sum \mathrm{X}}(-(-)\right.$

$\mathrm{n} \mathrm{n}$

2) The Standard deviation (SD) is calculated by the formula

$\mathrm{S} . \mathrm{D}=\sigma$ or $\mathrm{S}=\sum\left(\sqrt{\mathrm{X}-\overline{\mathrm{X}})^{2}}\right.$

3) The Standard error (SE) is calculated by the formula

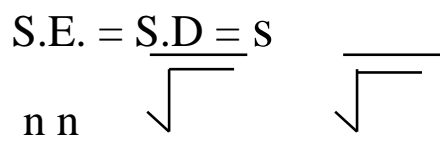

The Statistic ' $\mathrm{t}$ ' is calculated by the formula

$$
\underset{\mathrm{n}_{1}+\mathrm{n}_{2}}{\mathrm{SE}\left(\mathrm{m}_{1}-\mathrm{m}_{2}\right) \mathrm{S}_{1}^{2} \mathrm{~S}_{2}{ }^{2}} \frac{\left|\left(\mathrm{m}_{1}-\mathrm{m}_{2}\right)\right|}{\sqrt{\left(\square-\mathrm{m}_{2}\right) \mid}}
$$

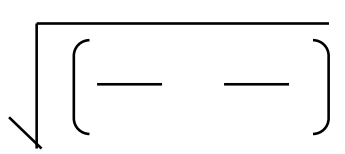

Where;

$\mathrm{m}_{1}=$ mean of the $1^{\text {st }}$ set of observations $n_{1}$

$\mathrm{m}_{2}=$ mean of the $2^{\text {nd }}$ set of observations $\mathrm{n}_{2}$

$\mathrm{s}_{1}=$ standard deviation of the sample of size $\mathrm{n}_{1}$

$\mathrm{s}_{2}=$ standard deviation of the sample of size $\mathrm{n}_{2}$

Degree of freedom (d.f ) is the number of independent variables: - Here d.f. $=\left(n_{1}-1\right)+\left(n_{2}-1\right)=\left(n_{1}+n_{2}\right.$ -2)

$\mathrm{P}$ - value is the standard table value of ' $\mathrm{t}$ ' at $(12-2)=10$ degree of freedom for $0.05(5 \%)$ level of significance.

$\mathrm{P}<0.05=$ significant or highly significant

$\mathrm{P}>0.05=$ not significant 